\title{
Intermediate wheatgrass and Russian wildrye responses to defoliation and moisture
}

\author{
J. R. HENDRICKSON AND J. D. BERDAHL
}

Authors are Rangeland Scientist and Research Plant Geneticist, respectively, Northern Great Plains Res. Lab, USDA-ARS, Box 459 Mandan, N.D.

\begin{abstract}
Perennial forage grasses in the Northern Great Plains are often grazed under water-limiting conditions. The effects of defoliation and soil moisture dynamics on herbage yield, tiller recruitment and number of crown positions for 2 perennial forage grasses were evaluated in a greenhouse experiment at Mandan, N.D. Intermediate wheatgrass (Thinopyrum intermedium (Host) Barkw. \& D.R. Dewey] and Russian wildrye (Psathyrostachys juncea (Fisch.) Nevski] were grown at 75,50 , or $40 \%$ of field capacity and left as undefoliated controls or defoliated at 10-day intervals to an 8- or 4-cm stubble height. Cumulative herbage yield exhibited defoliation level by soil moisture $(P=0.0001)$ and species by defoliation $(P=0.007)$ interactions. Yield decreased with increasing defoliation intensity at 75 and $50 \%$ of field capacity, but at $40 \%$ of field capacity only the most intense defoliation level was significantly affected. Russian wildrye produced more herbage $\left(1.97 \mathrm{~g} \mathrm{plant}^{-1}\right)$ than intermediate wheatgrass $(1.36$ $\left.\mathrm{g} \mathrm{plant}^{-1}\right)$ under severe defoliation level. Increased defoliation intensity $(P=0.0001)$ but not water availability $(P>0.05)$ decreased tiller numbers. Pooled across all treatments, Russian wildrye produced 10 tillers per plant and intermediate wheatgrass produced $7(P=0.0001)$. This may partially explain Russian wildrye's greater grazing tolerance. The number of crown positions (potential axillary bud sites in the bottom $20 \mathrm{~mm}$ of the plant) was similar between species suggesting that increased tiller numbers in Russian wildrye occurred because its axillary buds were more readily activated than intermediate wheatgrass. Moderate and severe defoliation reduced the number of crown positions on parent seedlings to only 62 and $50 \%$ of the number of crown positions of control seedlings, respectively. Water stress decreased $(P=0.004)$ number of crown positions at $40 \%$ of field capacity but only when crown positions of both parent and daughter tillers were pooled. In this experiment, defoliation had a greater effect than water stress. Moisture level mainly affected tiller size not numbers. The interaction between defoliation and water stress should be examined in field studies to foster improved management of these 2 grasses.
\end{abstract}

Key Words: (Psathyrostachys juncea), (Thinopyrum intermedium), Biomass, Tiller recruitment, Axillary buds,

U.S. Department of Agriculture, Agriculture Research Service, Northern Plains Area, is an equal opportunity/affirmative action employer and all agency services are available without discrimination. The authors would like to acknowledge the technical assistance of G. Jensen and W. Manchester and the comments of Drs. D. Meyer, K. Moore and D. Johnson on earlier versions of this manuscript.

Manuscript accepted 17 Mar. 01.

\section{Resumen}

Los pastos perennes en las Grandes Planicies del Norte (Northern Great Plains) son a menudo pastoreados bajo condiciones de escasez hídrica. Los efectos de la defoliación y de la dinámica de la humedad del suelo sobre la producción de forraje, reclutamiento de macollas y el número de posiciones en la corona se evaluaron en un experimento en invernaderos en Mandan, Dakota del Norte. Se cultivó Thinopyrum intermedium ((Host) Barkw \& D.R. Dewey) y Psathyrostachys juncea ((Fisch.) Nevski) a 75, 50, o $40 \%$ de la capacidad de campo y se dejaron como controles sin defoliar o defoliados, a intervalos de 10 días a 8- 4- cm de altura. La producción herbácea acumulativa mostró interacciones entre el nivel de defoliación y la humedad del suelo $(P=0.0001)$ y entre especie y defoliación $(P=0.007)$. La producción disminuyó con el aumento en la intensidad de la defoliación al 75 y $50 \%$ de la capacidad de campo, pero al $40 \%$ de la capacidad de campo, sólo el nivel más severo de defoliación tuvo un efecto significativo. $P$. juncea produjo más hierba $\left(1.97 \mathrm{~g}\right.$ planta $\left.{ }^{-1}\right)$ que $T$. intermedium (1.36 $\left.\mathrm{g}_{\text {planta }} \mathrm{t}^{-1}\right)$ en condiciones de defoliación severa. El aumento en la intensidad de defoliación $(P=0.0001)$ y no la disponibilidad de agua $(P>0.05)$ produjo una reducción en el número de macollas. Combinando todos los tratamientos, $P$. juncea produjo 10 macollas por planta mientras que $T$. intermedium produjo 7 ( $P=0.0001)$. Esto puede explicar parcialmente la mayor tolerancia al pastoreo de $P$. juncea. El número de posiciones en la corona (posiciones potenciales de yemas axilares en los $20 \mathrm{~mm}$ basales de la planta) fue similar entre las especies, lo que sugiere que el mayor número de macollas en $P$. juncea ocurrió debido a que sus yemas axilares fueron activadas más fácilmente que las de $T$. intermedium. La defoliación moderada y severa redujo el número de posiciones en la corona en las plantas progenitoras sólo en un 62 y $50 \%$ del número de posiciones en la corona en las plantas usadas como control, respectivamente. El estrés hídrico disminuyó $(P=0.004)$ el número de posiciones en la corona en el $\mathbf{4 0 \%}$ de la capacidad de campo, pero sólo cuando se combinaron las posiciones en la corona de la macolla madre con las de la hija. En este experimento la defoliación tuvo mayor efecto que el estrés hídrico. El nivel de humedad afectó especialmente el tamaño de las macollas pero no el número de ellas. La interacción entre la defoliación y el estrés hídrico debería ser examinada en estudios de campo para ayudar en el mejoramiento del manejo de estas 2 especies de pasto.

Perennial forage grasses in the Northern Great Plains are often grazed when moisture is limiting. If apical or intercalary meristems are removed by grazing, production of new tillers through activation of axillary buds is crucial to reestablish the photosyn- 
thetic canopy (Jewiss 1972). Limiting axillary bud production by a stress, such as drought, may adversely affect canopy regrowth and subsequent stand persistence (Busso et al. 1989). Understanding the interaction of drought and defoliation is paramount to development of viable grazing management guidelines for perennial forage grasses.

The ability to establish new tillers is an important trait associated with grazing tolerance in grasses. A comparative study of the grazing-sensitive bluebunch wheatgrass [Pseudoroegneria spicatum (Pursh) A. Löve] and the grazing-tolerant crested wheatgrass [Agropyron desertorum (Fisch. ex Link) Schult.] indicated ability to activate axillary buds was the primary mechanism affecting greater grazing tolerance of the latter (Caldwell et al.1981). Tiller recruitment from recently developed axillary buds contributed more to population persistence than did existing bud banks in sideoats grama [Bouteloua curtipendula (Michx.) Torr.] (Hendrickson and Briske 1997). Bud banks were considered to be buried viable populations of axillary buds in the soil (sensu Harper 1977 p. 109). However, axillary bud numbers are important, because, as a source of new tillers, they set a meristematic limit for future yields in perennial grasses, (Murphy and Briske 1992). Grazing and drought may adversely affect the ability of these axillary buds to initiate new tillers, and negatively affect stand persistence (Busso et al. 1989).

Intermediate wheatgrass [Thinopyrum intermedium (Host) Barkw. \& D.R. Dewey] and Russian wildrye [Psathyrostachys juncea (Fisch.) Nevski] are 2 perennial forage grasses planted in the Northern Great Plains. Intermediate wheatgrass will not tolerate frequent grazing and haying (Lawrence and Ashford 1966). Russian wildrye can withstand heavy utilization (Smoliak 1968), is drought tolerant (Asay et al. 1996) and maintains its nutritional value with advancing maturity (Knipfel and Heinrichs 1978). The objective of our greenhouse study was to determine the mechanisms affecting their different responses to grazing and moisture by evaluating the effects of 3 moisture levels and 3 defoliation levels on herbage yield and tiller and axillary bud numbers.

\section{Methods}

Plastic bags $(61 \times 66 \mathrm{~cm})$ were inserted into circular plastic pots with a radius of $11 \mathrm{~cm}$ and a height of $25 \mathrm{~cm}$. The pots were filled with $7,800 \mathrm{~g}$ of a mix of 8 parts soil, Parshall fine sandy loam (coarseloamy, mixed Pachic and Haploboralls) to 1 part vermiculite and 1 part peat moss. Field capacity of the soil was determined by hydrating the mix in $1,000 \mathrm{ml}$ graduated cylinders and then drying hydrated soil at $70^{\circ} \mathrm{C}$ and subtracting the dry weight from the hydrated weight. Soil was considered hydrated when the wetting front reached within $2.5 \mathrm{~cm}$ of the cylinder's bottom. Twelve seeds of either 'Mankota' Russian wildrye (Berdahl et al. 1992a), or 'Reliant' intermediate wheatgrass (Berdahl et al. 1992b) were placed at a depth of $2.5 \mathrm{~cm}$ in each pot on 13 February 1997. The greenhouse was kept at $21 \pm 3^{\circ} \mathrm{C}$ with 16 hours of light and 8 hours of darkness. Supplemental lighting was used to extend the light period. Pots were thinned to 9 plants after 2 weeks. Pots were watered to field capacity at the start of the experiment and were kept well watered until initial defoliation to ensure plants were generally at a morphological stage of Haun 3.5 (Haun 1973) at initial defoliation. Treatments were replicated 4 times in a factorial arrangement with 3 levels of defoliation and 3 levels of soil moisture. Defoliation treatments were: no defoliation (Control), defoliation to $8 \mathrm{~cm}$ stubble (Moderate) and defoliation to $4 \mathrm{~cm}$ stubble (Severe). Soil moisture treatments were 75,50 , and $40 \%$ of field capacity. Pots were weighed daily and watered as needed to maintain the appropriate moisture. Leaf water potentials were measured weekly on each species with a pressure chamber (Soil Moisture Corporation, Santa Barbara, Calif. ${ }^{1}$.

Of the 9 seedlings in each pot, the 3 in the center were identified as target seedlings prior to imposition of treatments. Target seedlings were defoliated and the remaining seedlings were not. In control treatments, target seedlings were not clipped until the end of the experiment. Defoliation began when plants had reached the 3.5 Haun stage (Haun 1973). Intermediate wheatgrass was more vigorous and reached the 3.5 Haun stage faster than Russian wildrye. Intermediate wheatgrass was initially clipped on 14 March 1997, about 2 weeks before Russian wildrye, and defoliations were repeated at approximately 10-day intervals thereafter. Prior to clipping, tiller numbers were recorded on the target seedlings, and

${ }^{1}$ Use of trade names is for information only and does not constitute an endorsement by USDA-ARS of any product to the exclusion of others that may be suitable. newly emerging tillers were marked with color-coded wires. All herbage removed during defoliation was stored in a paper bag and dried at $55^{\circ} \mathrm{C}$ for 3 days. Senescent plant material was also included with the harvested biomass. Plant material was considered senesced when it was detached or the leaf blade appeared dead. Senescent material from the control pots was removed at final harvest.

Defoliated treatments were clipped 6 times. After the final clipping, the 3 target seedlings were removed, the potting soil washed from their crowns and roots, and the above-ground herbage stored in plastic bags. Roots were removed from the crowns of 2 seedlings and the herbage was dried at $55^{\circ} \mathrm{C}$ for 3 days before weighing. Roots were not included in the herbage determination. The third seedling was dissected in the laboratory. After dissection, all herbage, excluding roots, was dried and weighed like the other 2 seedlings.

In the crown region of grasses are compressed phytomers, each of which consists of a node, internode, leaf, and axillary bud (Briske 1991) (Fig. 1). Removing leaves from the crown area often results in leaf scars. These are marks or scars on the crown where the sheath was attached to crown base. Not all leaf axils contain buds (Mueller and Richards 1986), so leaf scars are important because they indicate the position of a potential bud when there are no visible bud scars. By counting the number of leaf scars, axillary buds and emerged tillers in the crown region (bottom $20 \mathrm{~mm}$ of the seedling), we were able to estimate the number of potential axillary bud sites or crown positions. The crown positions that did not develop into new tillers were classified as: 1) buds, i.e. developed axillary buds; 2) missing buds, i.e. axillary buds that were lost during processing, and 3) leaf scars.

Following dissection, seedling crowns were placed into 2,3,5-triphenyl tetrazolium chloride (TTC) solution for 22 hours at room temperature, which made buds more visible and improved the assessment of their viability. After removing the crowns from the stain, crown positions on the parent seedling and daughter tillers were counted using a dissecting microscope.

The experiment was analyzed as a randomized complete block with 2 species, 3 levels of defoliation and 3 levels of moisture availability in a factorial arrangement of treatments using SAS GLM procedures (SAS 1990). An experimental unit was a pot and the 3 target seedlings within a pot. Herbage yields and tiller numbers were $\log$ transformed to correct for heterogene- 


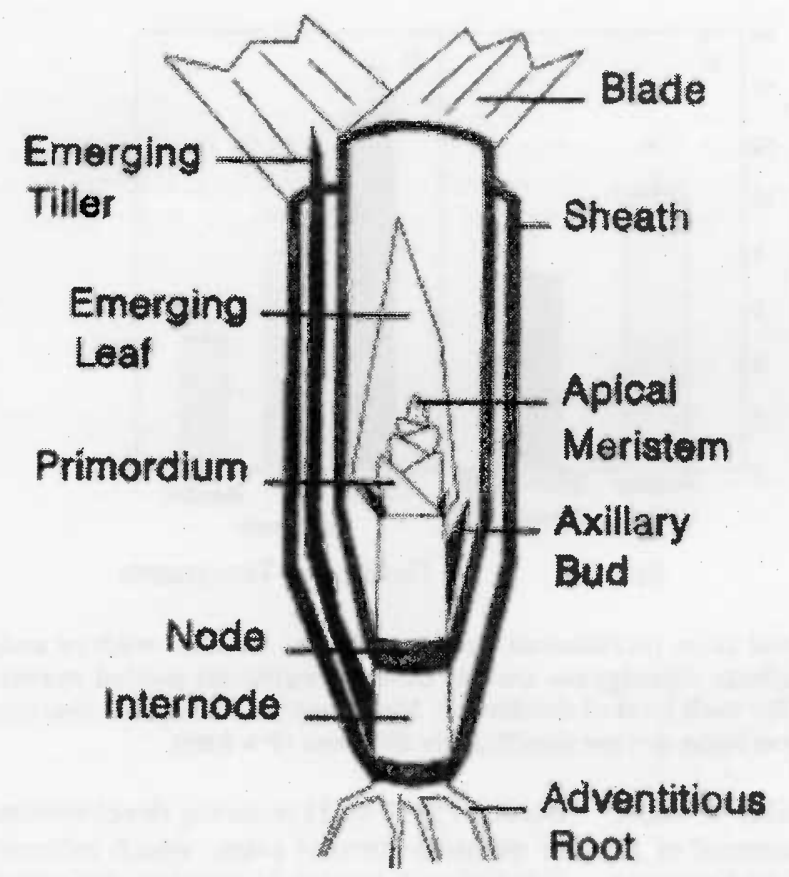

Fig. 1. Longitudinal view of a grass tiller showing the crown area. Note the node, internode, leaf and axillary bud that make up a phytomer. Emerging tillers begin as axillary buds. Crown positions were considered as to be sites where there was an axillary bud or emerging tiller. Identifying leaf scars or the areas where the leaf sheath was attached to the crown facilitated locating these positions (Figure redrawn from Murphy and Briske 1992).

ity of variance. Herbage yield was expressed as cumulative biomass from all harvest dates including senesced material but excluding roots. Tiller numbers were expressed as cumulative number of tillers emerged per seedling including parent and daughter tillers. Results are presented with untransformed values for clarity. Analysis of the number of crown positions on the parent seedling (parental crown positions) and on the parent seedling and its daughter tillers (combined crown positions) did not detect heterogeneity of variances, so transformation was not required. Mean separation for all variables employed LSD procedures $(P \leq 0.05)$.

\section{Results}

\section{Herbage Yields}

Mean leaf water potentials pooled across time and defoliation treatments for both species are found in Table 1. Russian wildrye water potentials were consistently more negative than intermediate wheatgrass.

Herbage yield exhibited both defoliation by water availability $(\mathrm{P}=0.0001)$ and species by defoliation $(\mathrm{P}=0.007)$ interactions. Yields decreased with increasing tion (Fig. 3).

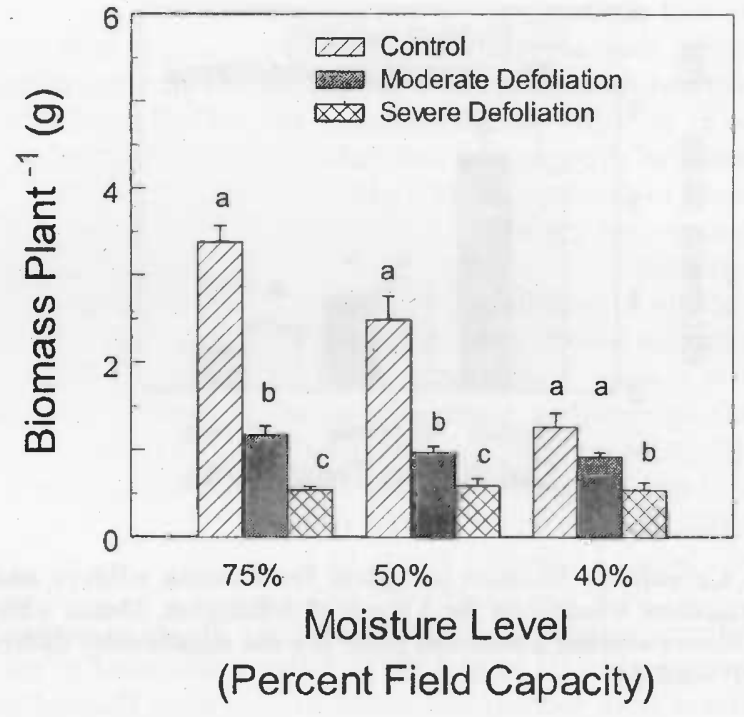

Fig. 2. Cumulative biomass per plant for three defoliation levels under 3 levels of water stress. Biomass was averaged across species and represents the total yield over time. Means within a cluster sharing a common letter are not significantly different $(P>0.05)$. defoliation intensity at 75 and $50 \%$ of field capacity but not among control and moderately defoliated plants at $40 \%$ of field capacity (Fig. 2). Yields of undefoliated plants at $40 \%$ of field capacity were similar to moderately defoliated plants at $75 \%$ of water holding capacity. Under severe defoliation, Russian wildrye produced more biomass $(\mathrm{P}<0.05)$ than intermediate wheatgrass generating a species $\mathrm{x}$ defoliation interac-

\section{Tiller Numbers}

Tiller numbers were affected by species $(\mathrm{P}=0.0001)$ and defoliation level $(\mathrm{P}=$ $0.0001)$ but not by moisture treatments $(P$ $=0.112$ ). There were no significant interactions $(P>0.05)$. Russian wildrye seedlings averaged 10 tillers per plant $(\mathrm{P}<$ 0.05 ) compared to 7 for intermediate wheatgrass (Fig. 4A). Tillers per plant decreased $(\mathrm{P}<0.05)$ with increasing defo- liation (Fig. 4B). Control plants produced 2.7 times more tillers as severely defoliated plants and 1.6 times more tillers than moderately defoliated plants.

\section{Crown Positions}

Both grasses had similar $(P=0.213)$ numbers of crown positions. Most crown positions on intermediate wheatgrass were primarily axillary buds $(51 \%)$ and new tillers (41\%). Axillary buds comprised $38 \%$ and new tillers $61 \%$ of the crown positions on Russian wildrye. The remaining crown positions ( 8 and $1 \%$ for intermediate wheatgrass and Russian wildrye respectively) were either leaf scars or missing buds.

Crown positions of the parent seedlings were affected by defoliation $(\mathrm{P}=0.0001)$ but not by moisture level $(P=0.214)$ (Fig. $5 \mathrm{~A}$ and $5 \mathrm{~B}$ ). Moderate and severe defoliation treatments had fewer parental crown positions than the control treatments. The number of crown positions on a parent seedling and its daughter tillers (combined
Table 1. Mean water potential and standard errors $(n=32)$ for Russian wildrye and intermediate wheatgrass pooled across time and defoliation treatments.

\begin{tabular}{lccc}
\hline \hline & \multicolumn{3}{c}{$\begin{array}{c}\text { Moisture level } \\
\text { (Percent of field capacity) }\end{array}$} \\
Species & $75 \%$ & $50 \%$ & $40 \%$ \\
\hline & $-0.75 \pm 0.02$ & $-1.12 \pm 0.11$ & $-1.60 \pm 0.13$ \\
Russian Wildrye & $-0.64 \pm 0.11$ & $-1.00 \pm 0.16$ & $-1.12 \pm 0.13$ \\
\hline
\end{tabular}




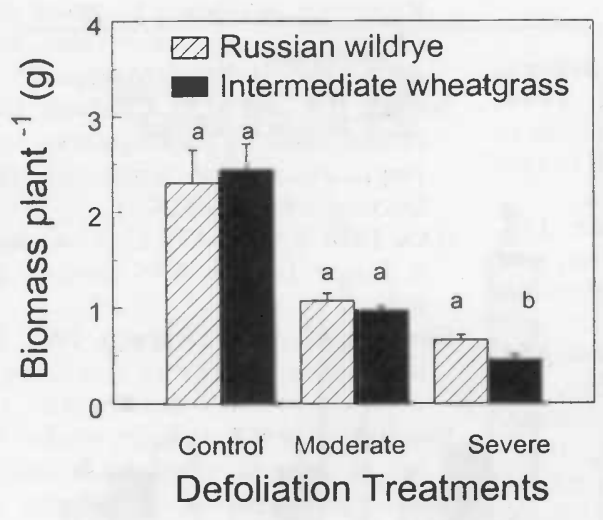

Fig. 3. Cumulative biomass per plant for Russian wildrye and intermediate wheatgrass for 3 levels of defoliation. Means within a cluster sharing a common letter are not significantly different $(P>0.05)$.

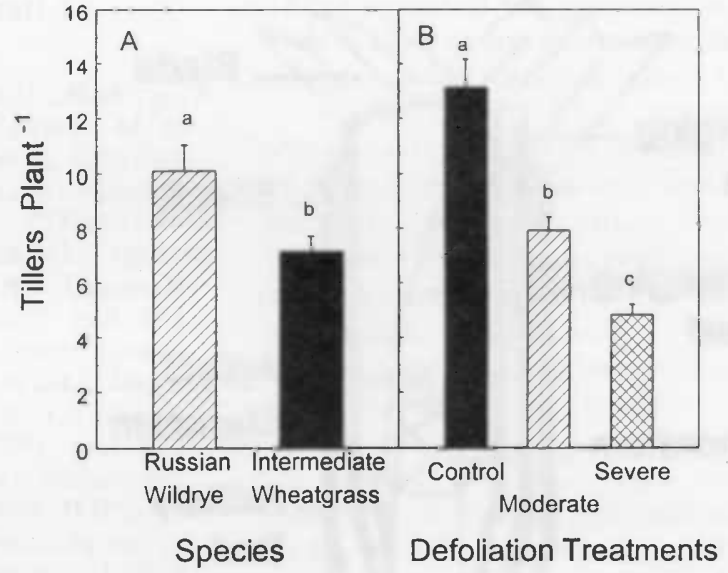

Fig. 4. Total tiller recruitment per plant for A) Russian wildrye and intermediate wheatgrass and B) tiller recruitment pooled across species for each level of defoliation. Means within each panel sharing a common letter are not significantly different $(P>0.05)$. crown positions) was affected by defoliation $(P=0.0001)$ and moisture level $(P=$ $0.004)$ but not species $(P=0.372)$. There were no significant $(P>0.05)$ interactions for the combined crown positions. Combined crown positions were reduced at $40 \%$ but not at 50 and $75 \%$ of field capacity (Fig. 5C). The number of combined crown positions decreased as defoliation level increased (Fig. 5D).

\section{Discussion}

The level of defoliation had a greater effect on plant response than moisture level in our study. Control plants generally produced more herbage, more tillers and more crown positions than defoliated plants and both herbage yield and tiller numbers decreased as the level of defoliation increased.

An earlier study of drought and defoliation effects in Russian wildrye and crested wheatgrass, 2 grazing tolerant grasses, found lightly defoliated plants produced more herbage than controls (Mohammed et al. 1982). In our study, herbage yield decreased with increasing level of defoliation in both grasses. Russian wildrye, which is known for its ability to persist under heavy grazing (Smoliak 1968) and drought (Asay et al. 1996), produced significantly more biomass with severe defoliation than intermediate wheatgrass.

With our driest treatment, biomass was similar between moderately defoliated and lindefoliated plants. Mean leaf water potentials in our study were not as negative than those reported for 2 tropical $C_{4}$ grasses (Simones and Baruch 1991) (-3.0 to $-3.5 \mathrm{MPa}$ ) but were similar to those $(-1.3$ to $-1.6 \mathrm{MPa})$ of Mohammad et al. (1982) in Russian wildrye and crested wheatgrass. Our plants were defoliated sooner and at shorter intervals than in Mohammad et al.'s (1982) study, which may partially explain the differences between our results and theirs. Our moderate defoliation ( $8 \mathrm{~cm}$ stubble height) approximated the light defoliation treatment ( $7 \mathrm{~cm}$ stubble height) of Mohammad et al. (1982).

Water stress has been shown to decrease the effect of defoliation in grasses (Fennema and Briede 1990, Simones and
Baruch 1991) by 1) reducing development of moisture stressed plants which reduces defoliation intensity 2) slowing the onset of water stress in defoliated plants, 3 ) suspension of leaf aging and 4) an interaction of all of these (Simones and Baruch 1991). In our study, herbage yield of control plants declined when water was limiting but yields of moderately and severely defoliated plants were approximately the same regardless of moisture level. As a result, yields of control and moderately defoliated plants were similar at $40 \%$ of field capacity. The decline in biomass across moisture levels for control plants

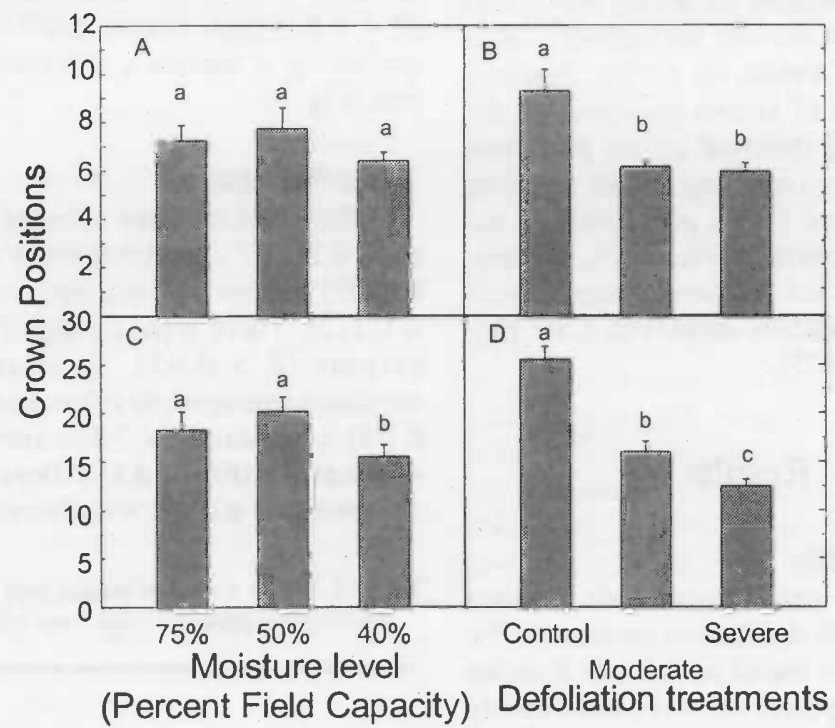

Fig. 5. Number of crown positions per parent seedling as affected by moisture level (A) and defoliation (B) and combined parent seedling and daughter tillers as affected by moisture level (C) and defoliation (D). Means within each panel sharing a common letter are not significantly different $(\mathbf{P}>\mathbf{0 . 0 5})$. 
supports Simones and Baruch's (1981) speculation that reduction in yield of water stressed plants effectively reduces defoliation intensity.

Defoliation had a greater effect on tiller recruitment than water stress. Except for the crown positions on the parent and daughter tillers (combined crown positions) at $40 \%$ of field capacity, water stress did not affect current tiller recruitment or the number of crown positions. Our reduced yields, therefore, were simply a product of smaller tillers. Defoliation, however, decreased both realized and potential tiller recruitment via depression of axillary bud numbers. Axillary buds probably set a meristematic limit on future yields because they are the source of new tillers (Murphy and Briske 1992) and defoliation probably has a larger impact on potential yields than water stress.

Rapid development of new tillers is a common characteristic of grazing-tolerant grasses (Caldwell et al. 1981, Nowak and Caldwell 1984). Russian wildrye can withstand heavy grazing (Smoliak 1968) and, in our study, produced approximately 3 more tillers per plant than the grazing-sensitive intermediate wheatgrass. The number of crown positions did not differ between species so Russian wildrye simply had a greater ability to activate new tillers.

Our findings help explain some of the dynamics observed in intermediate wheatgrass and Russian wildrye pastures. We noted that reduced moisture levels lowered herbage production but did not affect realized or potential tiller recruitment in these grasses. Severe defoliation, however, retarded both tiller recruitment and development of axillary buds necessary for subsequent growth. The greater tiller recruitment of Russian wildrye potentially explains its greater grazing tolerance compared to the more grazing sensitive intermediate wheatgrass. Regardless of the species, we suggest that managers protect the productive potential of their pastures by not severely defoliating their forages. This research suggests that proper grazing management is important regardless of the moisture situation. More research is needed on these grasses, however, to evaluate the effects of grazing management and drought on well-established plants in applied circumstances.

\section{Literature Cited}

Asay, K.H., D.A. Johnson, K.B. Jensen, W.M. Sarraj, and D.H.Clark. 1996. Potential of new tetraploid germplasm in Russian wildrye. J. Range Manage. 49:439-442.

Berdahl, J.D., R.E. Barker, J.F. Karn, J.M. Krupinsky, R.J. Haas, D.A. Tober, and I.M. Ray. 1992a. Registration of 'Mankota' Russian wildrye. Crop Sci. 32:1073.

Berdahl, J.D., R.E. Barker, J.F. Karn, J.M. Krupinsky, R.J. Haas, D.A. Tober, and I.M. Ray. 1992b. Registration of 'Reliant' intermediate wheatgrass. Crop Sci. 32: 1072.

Briske, D.D. 1991. Developmental morphology and physiology of grasses. p. 85-108. In: R.K. Heitschmidt and J.W. Stuth (ed.) Grazing management: an ecological perspective. Timber Press, Portland, Ore..

Busso, C.A., R.J. Mueller, and J.H. Richards. 1989. Effects of drought and defoliation on bud viability in two caespitose grasses. Ann. Bot. 63:477-485.

Caldwell, M.M., J.H. Richards, D.A. Johnson, R.S. Nowak, and R.S. Dzurec. 1981. Coping with herbivory: Photosynthetic capacity and resource allocation in two semiarid Agropyron bunchgrasses. Oecologia 50:14-24.

Fennema, F. and J.W. Briede. 1990. The effect of clipping and drought on the production of selected grass species in the Yemen Arab Republic. J. Arid Environ. 19:119-124.

Harper, John L. 1977. Population biology of plants. Academic Press Ltd. 24-28 Oval Road, London, NW1.

Haun, J.R. 1973. Visual quantification of wheat development. Agron. J. 65:116-119.

Hendrickson, J.R. and D.D. Briske. 1997. Axillary bud banks of two semiarid perennial grasses: Occurrence, longevity, and contribution to population persistence. Oecologia 110 (4): 584-591.

Jewiss, O.R. 1972. Tillering in grasses: Its significance and control. J. Br. Grassl. Soc. 27: 65-82.

Knipfel, J.E. and D.H. Heinrichs. 1978. Nutritional quality of crested wheatgrass, Russian wild ryegrass, and Altai wild ryegrass throughout the grazing season in southwestern Sask. Can. J. Plant Sci. 58-581-582.

Lawrence, T. and R. Ashford. 1969. The productivity on intermediate wheatgrass as affected by initial harvest dates and recovery periods. Can. J. Plant Sci. 46:9-15.

Mohammad, N., D.D. Dwyer, and F.E. Busby. 1982. Responses of crested wheatgrass and Russian wildrye to drought and defoliation. J. Range Manage. 35:227-230.

Mueller, R.J. and J.H. Richards. 1986. Morphological analysis of tillering in Agropyron spicatum and Agropyron desertorum. Annu. of Bot. 58:911-921.
Murphy, J.S. and D.D. Briske. 1992. Regulation of tillering by apical dominance: Chronology, interpretive value, and current perspectives. J. Range Manage. 45:419-429.

Nowak, R.S. and M.M. Caldwell. 1984. A test of compensatory photosynthesis in the field: implications for herbivory tolerance. Oecologia 61:311-318.

SAS. 1990. SAS/STAT7 User's Guide, Version 6, Fourth Edition. SAS Institute Inc. Cary, N.C.

Simones, M. and Z. Baruch. 1991. Responses to simulated herbivory and drought in two tropical $C_{4}$ grasses. Oecologia 88: 173-180.

Smoliak, S. 1968. Grazing studies on native range, crested wheatgrass, and Russian wildrye pastures. J. Range Manage. 21:47-50. 